\title{
Enhancement of pullulanase production from recombinant Bacillus subtilis by optimization of feeding strategy and fermentation conditions
}

\author{
Yu Zhang ${ }^{1}$, Yao Nie ${ }^{1 *} \mathbb{D}, \mathrm{Xia}_{\text {Zhou }}{ }^{1}$, Jiahua $\mathrm{Bi}^{1}$ and $\mathrm{Yan} \mathrm{Xu^{1,2 }}$
}

\begin{abstract}
Pullulanase is an important starch-debranching enzyme mostly used in starch processing-related food industries. However, the levels of pullulanase produced from recombinant Bacillus subtilis, a Generally Recognized as Safe (GRAS) host, are generally limited. To enhance the activity of pullulanase, batch fermentation and fed-batch fermentation were systematically investigated. The overall purpose is to improve the fermentation yield by optimizing the feeding strategy in the fermentation process, thereby increasing the enzyme activity of pullulanase. Therefore, in this study, the feeding methods, the feeding ingredients, the feeding concentration, and $\mathrm{pH}$ values were studied in detail. The optimized fermentation conditions for pullulanase production from recombinant B. subtilis were determined as following: inoculum volume 7\%, pH 6.5, the dissolved oxygen level 30\%, and constant-rate feeding of $100 \mathrm{~mL}$ glucose solution $\left(400 \mathrm{~g} \mathrm{~L}^{-1}\right)$ in late logarithmic growth. The $\mathrm{OD}_{600}$ of recombinant B. subtilis and enzyme activity were 84.54 and $102.75 \mathrm{U} \mathrm{mL}^{-1}$, which were respectively $141 \%$ and $144 \%$ higher than that before optimization. These findings provided a prerequisite for further amplification of the fermentation system to obtain higher enzyme activity.
\end{abstract}

Keywords: Pullulanase, Bacillus subtilis, Fermentation process, Optimization, Feeding strategy

\section{Introduction}

Pullulanase (EC 3.2.1.41) is a class of debranching enzymes that catalyze the hydrolysis of alpha-1, 6-glucosidic linkages of unmodified substrates (Nakamura 1996, van der Maarel et al. 2002). The capability of the pullulanase to decompose the branches makes it widely used in various fields, which emphasizes its leading role as one of the promising new varieties of amylases (Leathers 2003). Pullulanase is widely used in the different kinds of industrial fields. In the starch industry, pullulanase and amylase can improve the efficiency of starch saccharification and reduce the cost. At present, the starch industry is

\footnotetext{
${ }^{*}$ Correspondence: ynie@jiangnan.edu.cn

1 School of Biotechnology and Key Laboratory of Industrial Biotechnology of Ministry of Education, Jiangnan University, 1800 Lihu Road,

Wuxi 214122, China

Full list of author information is available at the end of the article
}

based on starch raw materials, and the starch in the raw materials has nearly three-quarters of amylopectin. In addition, pullulanase also plays an outstanding role in the pharmaceutical and feed industry as well (Shiraishi et al. 1985).

Bacillus subtilis, as a GRAS strain, has many advantages and is used in a wide range of applications as expression host for production of food processing-related enzymes. Lack of an outer membrane and a significant bias in codon usage lead to more efficient secretion (Beaulieu et al. 2005) and allow efficient transcription and translation of the target protein. Although there are many types and sources of pullulanase that have been previously reported, there are still some limitations in using B. subtilis system in respect of the yield and activity of this enzyme (Kang et al. 2011, Singh et al. 2010). The approaches involving recombinant constructions have 
been adopted for enhancing heterologous expression of pullulanases. Deng et al. (2018) developed B. subtilis WB800/pMA0911-PsacB-pul-degQ (N) for pullulanase production by optimizing the enhancer of the recombinant strain, with the enzyme activity reaching 26.5 $\mathrm{U} \mathrm{mL}^{-1}$ in the shake flask. Moreover, the enzyme production can be mildly enhanced by optimization of the fermentation medium and general conditions. Liu et al. optimized the fermentation medium and fermentation conditions to achieve the enzyme activity of pullulanase of $20.16 \mathrm{U} \mathrm{mL}^{-1}$ from B. subtilis WB600/pWB-pulB (Liu et al. 2012a). Since different microorganisms have their favorable process and conditions for growth and production of metabolites, it would be important to explore suitable fermentation mode and optimize fermentation process.

The level of production by biological fermentation depends not only on the performance of the production strain itself, but also on providing suitable fermentation conditions in order to fully utilize its production capacity (Kubiak et al. 2019). Optimizing the fermentation process can fully exploit the potential of the strain, improve the production efficiency of the fermentation process, and reduce the production cost (Wang et al. 2018). Therefore, the research on process optimization is especially important. In fermentation production, the reaction conditions can be artificially regulated directly or indirectly. The temperature, $\mathrm{pH}$ value, dissolved oxygen, and other factors in the fermentation process will affect the growth and metabolism of microorganisms. Wang et al. (2014) optimized the fermentation condition of alkaline amylase from the recombinant strain B. subtilis WB800, which was 3.36 times higher than that before optimization. Huang et al. (2004) have greatly improved the production of $B$. subtilis amylase by optimizing the feeding strategy.

There are many kinds of feeding strategies, which are divided into feedback feeding and non-feedback feeding. According to the feeding speed, they are divided into constant speed feeding and index feeding. By exploring different optimization fermentation methods, the production efficiency of the fermentation process can be effectively improved, leading to the lower production costs (Gao and Shi 2013). Optimal fermentation conditions and appropriate feeding strategies are critical for cell growth and protein expression (Yadav et al. 2017).

In this work, we studied the differences between batch fermentation and fed-batch fermentation, and further explored the characteristics of two feeding strategies, DO-stat feeding strategy and constant-rate feeding strategy. The optimum feeding carbon source and optimum concentration were determined by adding different concentrations of glucose and sucrose under constantrate feeding. Afterwards, we investigated the effects of fermentation system $\mathrm{pH}$ value on the process. Finally, the enzyme activity of the recombinant pullulanase was determined after combining the optimized fermentation conditions.

\section{Materials and methods}

Strains, media, and growth conditions

B. subtilis WB800- $\mathrm{P}_{\text {HpaII }}$ - pul used in this study was constructed in our laboratory (Wang et al. 2019a, b). B. subtilis WB800 was employed for the host for recombinant pullulanase production. Pullulanase (GenBank Accession No. JN872757) was from B. naganoensis. The pullulan polysaccharide used to determine the activity of pullulanase was purchased from Tokyo Kasei Kogyo Co., Ltd (Tokyo, Japan). Prime STAR Max DNA Polymerase was obtained from TaKaRa Biotechnology Co., Ltd. (Dalian, China). The DNA primers were obtained from Shanghai Sangon Biological Engineering Technology \& Services Co., Ltd. (Shanghai, China). All other reagents were of analytical grade and were commercially available unless otherwise indicated.

\section{Media and feeding solutions}

Luria-Bertani (LB) broth or agar plate was composed for $10 \mathrm{~g} \mathrm{~L}^{-1}$ tryptone, $5 \mathrm{~g} \mathrm{~L}^{-1}$ yeast extract, and $10 \mathrm{~g} \mathrm{~L}^{-1}$ $\mathrm{NaCl}$, supplementing with $2 \%$ agar power. Seed cultures were grown in medium that contained sucrose $40 \mathrm{~g} \mathrm{~L}^{-1}$, soy peptone $30 \mathrm{~g} \mathrm{~L}^{-1}, \mathrm{KH}_{2} \mathrm{PO}_{4} 6 \mathrm{~g} \mathrm{~L}^{-1}, \mathrm{MgCl}_{2} \cdot 6 \mathrm{H}_{2} \mathrm{O}$ $2.04 \mathrm{~g} \mathrm{~L}^{-1}$. The composition of fermentation medium were sucrose $70 \mathrm{~g} \mathrm{~L}^{-1}$, soy peptone $50 \mathrm{~g} \mathrm{~L}^{-1}, \mathrm{KH}_{2} \mathrm{PO}_{4}$ $5 \mathrm{~g} \mathrm{~L}^{-1}$, and $\mathrm{MgCl}_{2} \cdot 6 \mathrm{H}_{2} \mathrm{O} 3.06 \mathrm{~g} \mathrm{~L}^{-1}$. The feeding solutions of fed-bath fermentation contained different concentrations of glucose solutions $\left(300 \mathrm{~g} \mathrm{~L}^{-1}, 400 \mathrm{~g} \mathrm{~L}^{-1}\right.$, and $\left.500 \mathrm{~g} \mathrm{~L}^{-1}\right)$ and sucrose solutions $\left(400 \mathrm{~g} \mathrm{~L}^{-1}\right)$.

\section{Seed culture}

Frozen glycerol strain stored at $-20^{\circ} \mathrm{C}$ was streaked into LB solid plates, and then activated by incubating at $37^{\circ} \mathrm{C}$ for 10-12 h. A single colony was picked into test tube, which contained $5 \mathrm{~mL}$ seed culture medium, culturing at $37^{\circ} \mathrm{C}, 220 \mathrm{r} \mathrm{min}^{-1}$ on a constant temperature shaker for 10-12 $\mathrm{h}$ The activated seed solution was transferred into $500 \mathrm{~mL}$ shake flasks containing $50 \mathrm{~mL}$ of seed culture medium on a rotary shaker. The inoculum amount was $7 \%(\mathrm{v} / \mathrm{v})$, and cultured at $37^{\circ} \mathrm{C}, 220 \mathrm{r} \mathrm{min}^{-1}$ on a constant temperature shaker for $8-10 \mathrm{~h}$.

\section{Bioreactor fermentation}

Bioreactor cultivation was performed in a $3 \mathrm{~L}$ fermenter (BioFlo110, New Brunswick Scientific co., Inc.). The liquid volume was $1 \mathrm{~L}$, the ventilation volume was $1.5 \mathrm{vvm}$, and the initial stirring speed was $300 \mathrm{rpm}$. The $7 \%$ seed culture was added to the modified semisynthetic medium 
for batch or fed-batch cultivation. The fed-batch fermentation required feeding carbon source. According to different methods, we chose the DO-Stat feeding strategy and the constant-rate feeding strategy, feeding $100 \mathrm{~mL}$ sucrose solution $\left(400 \mathrm{~g} \mathrm{~L}^{-1}\right)$ separately. The biomass and enzyme activity were monitored regularly. Considering the effect of the carbon source type on the fermentation, we selected glucose solution $\left(400 \mathrm{~g} \mathrm{~L}^{-1}\right)$ as feeding solution for comparison with sucrose solution $\left(400 \mathrm{~g} \mathrm{~L}^{-1}\right)$. Then, in order to determine the optimal carbon source concentration, we set up three concentration gradients of $300 \mathrm{~g} \mathrm{~L}^{-1}, 400 \mathrm{~g} \mathrm{~L}^{-1}$, and $500 \mathrm{~g} \mathrm{~L}^{-1}$ for experiments, respectively. According to the relevant report, the addition of carbon source can affect the acidity and alkalinity of the fermentation broth (Wang et al. 2018), and thus the $\mathrm{pH}$ was finally optimized.

\section{Biomass of $B$. subtilis and enzyme activity assay}

Biomass was monitored by measuring the optical density at $600 \mathrm{~nm}\left(\mathrm{OD}_{600}\right)$. After appropriately diluting the fermentation broth containing the cells, the values of $\mathrm{OD}_{600}$ were measured using a $721 \mathrm{UV}-\mathrm{Vis}$ spectrophotometer (Labbeiki et al. 2014).

Enzymatic activity of pullulanase was determined by measuring the generated aldehyde groups released from enzymatic saccharification with pullulan as the substrate (Chen et al. 2012). We sampled regularly during the fermentation process and centrifuged for $10 \mathrm{~min}$ at $12,000 \mathrm{rpm}$, then collected the supernatant and diluted to a suitable multiple with buffer solution $(0.1 \mathrm{M}, \mathrm{pH}$ 4.5 sodium acetate and acetic acid buffer). $200 \mu \mathrm{L}$ of $2 \%$ pullulan substrate and $200 \mu \mathrm{L}$ of the diluted fermentation broth were mixed and placed in a water bath at $60{ }^{\circ} \mathrm{C}$ for $20 \mathrm{~min}$ as an experimental group. The control group added $200 \mu \mathrm{L}$ of substrate after the reaction. The two groups were added with $600 \mu \mathrm{L}$ of 3,5-dinitrosalicylic acid (DNS), placed in a boiling water bath for $5 \mathrm{~min}$, cooling down and then added with $3 \mathrm{~mL}$ of ultrapure water. $200 \mu \mathrm{L}$ of the sample was transferred in 96-well plate and absorbance at $540 \mathrm{~nm}$ wavelength was measured in microplate reader. Three parallel experiments were set up in each group and the results were finally averaged. One unit of pullulanase enzyme activity was defined as the amount of enzyme required to catalyze the decomposition of the substrate of pullulan to produce a reducing sugar (equivalent to $1 \mu \mathrm{mol}$ of glucose) per minute under the reaction conditions.

\section{Results}

Cultivation of recombinant strain by batch fermentation

The strain B. subtilis WB800- $\mathrm{P}_{\text {HpaII }}$ pul was cultured in $3 \mathrm{~L}$ fermenter for $50 \mathrm{~h}$. During the batch fermentation process, the temperature and dissolved oxygen level were maintained at $37{ }^{\circ} \mathrm{C}$ and $30 \%$, respectively, and $\mathrm{pH}$ value was natural. The biomass and enzyme activity were measured at regular intervals. As shown in Fig. 1, the recombinant strain showed slow growth in the first $2 \mathrm{~h}$, and then it grew rapidly from the next $14 \mathrm{~h}$. The biomass did not increase after the cells entered the stable phase; the maximum value of $\mathrm{OD}_{600}$ was 35.12. After fermentation for $32 \mathrm{~h}$, the enzyme activity reached the maximum value of $42.15 \mathrm{U} \mathrm{mL}^{-1}$. In the early stage of fermentation, the enzyme activity of pullulanase increased remarkably with increasing the recombinant strain concentration. After $32 \mathrm{~h}$, the enzyme activity decreased slightly but overall remained unchanged.

In general, heterologous protein expression lagged behind the growth of $B$. subtilis and was closely related to it. During the fermentation process, the $\mathrm{pH}$ value continued to rise with the consumption of the carbon source, reaching about 7.5 at $50 \mathrm{~h}$. The consumption of nutrients and the accumulation of metabolic waste in the late stage of fermentation might be the main reasons for limiting the growth of the recombinant strain and expression of heterologous protein (Liu et al. 2008). With the purpose of providing sufficient carbon sources, we intended to optimize the feeding way and fed-batch strategy of fermentation process in the next experiment.

\section{Effects of feeding ways of fed-batch fermentation}

In order to obtain high-density recombinant cell concentrations during fermentation process and avoid substrate inhibition and accumulation of metabolic product, fed-batch fermentation strategy was proposed. By adding fresh feeding to the bioreactor, it would be feasible to overcome the premature termination of fermentation

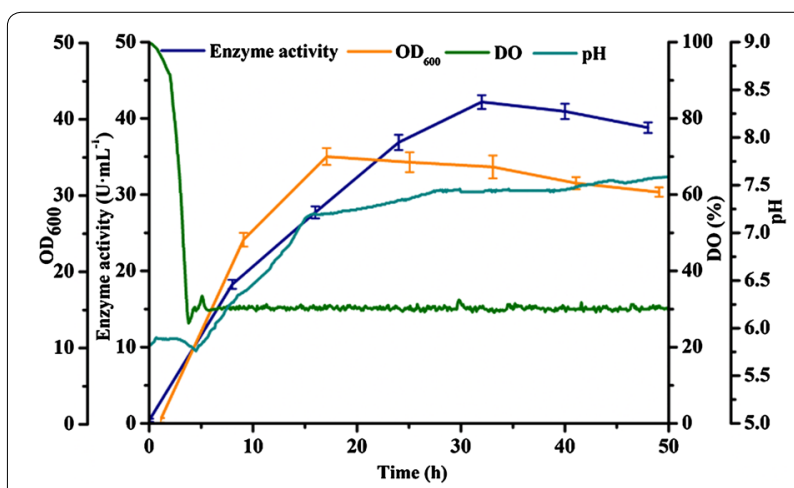

Fig. 1 Batch fermentation of the recombinant strain B. subtilis WB800-P $\mathrm{P}_{\text {Hpall }}$-pul. The values of $\mathrm{OD}_{600}$ (orange curve), extracellular enzyme activity (blue curve), dissolved oxygen (green curve), and pH (light blue curve) were measured during the fermentation process. The averages of three independent experiments together with the corresponding standard deviations are shown for all values of $\mathrm{OD}_{600}$ and enzyme activity 
due to insufficient nutrients (Park et al. 1992). Fed-batch culture was a method that referred to the intermittent or continuous addition of one or more specific restricted substrates to the fermenter during batch culture until the end of the fermentation process followed by the discharge of culture (Son et al. 2007).

To study the effect of feeding ways on the production of pullulanase, we have adopted two common strategies: constant-rate feeding (non-feedback feeding strategy) and DO-stat feeding (feedback feeding strategy) (Table 1). The constant-rate feeding strategy was easy to operate, and the feeding was continuously fed at a constant rate (Prentice et al. 2007). The source continuously supplied energy to the cells, which could meet the needs of growth and expression of foreign proteins. The second feeding strategy was more intuitive to reflect the state of fermentation (Zhu et al. 2015). It was monitored by the on-line detection device of dissolved oxygen, and once the dissolved oxygen rebounded, the feeding was added to maintain the stability of DO. Both methods had their own advantages; therefore, we performed further experiments to find out which fermentation process was more suitable for this study.

After carbon in the fermentation broth was consumed in a large amount, the oxygen consumption of the cells decreased due to the lack of nutrients, and the dissolved oxygen concentration rose rapidly (Liu et al. 2012b). However, the dissolved oxygen concentration decreased again after the addition of carbon. In this way, the dissolved oxygen concentration could be maintained at a constant level. For DO-Stat feeding fed-batch fermentation, the dissolved oxygen gradually decreased during the initial stage of fermentation. As shown in Fig. 2a, when the dissolved oxygen was reduced to $30 \%$, it was coupled with the rotational speed, and soon after, the dissolved oxygen was restored to $30 \%$. When the dissolved oxygen suddenly rose, the carbon source was added. When fermenting for $15 \mathrm{~h}$, the maximum value of $\mathrm{OD}_{600}$ was 37.68 and when fermenting for $30 \mathrm{~h}$, the enzyme activity reached the maximum value of $46.49 \mathrm{U} \mathrm{mL}^{-1}$.

For constant-rate feeding, the biomass of B. subtilis increased dramatically in the logarithmic growth phase, so that the carbon source was quickly consumed. Feeding time earlier or later was not conducive to the accumulation of the target product. Feeding at an earlier time would stimulate cell growth and accelerate consumption of carbon source; on the contrary, feeding at a deferred time would lead to insufficiency of nutrients and postpone the growth of the recombinant strain. By supplementing more carbon source, the $\mathrm{OD}_{600}$ and enzyme activity were also increased. As shown in Fig. 2b, similar to the batch fermentation process, the recombinant strain

Table 1 Comparison of two feeding strategies

\begin{tabular}{lllll}
\hline Strategy & Time & Rate $\left(\mathbf{m L ~ m i n}^{\mathbf{- 1}}\right)$ & Volume $(\mathbf{m L})$ & Ingredient \\
\hline DO-stat feeding & DO rebound period & 0.1 & 100 & Sucrose \\
Constant-rate feeding & Late logarithmic growth & 0.1 & 100 & Sucrose \\
\hline
\end{tabular}
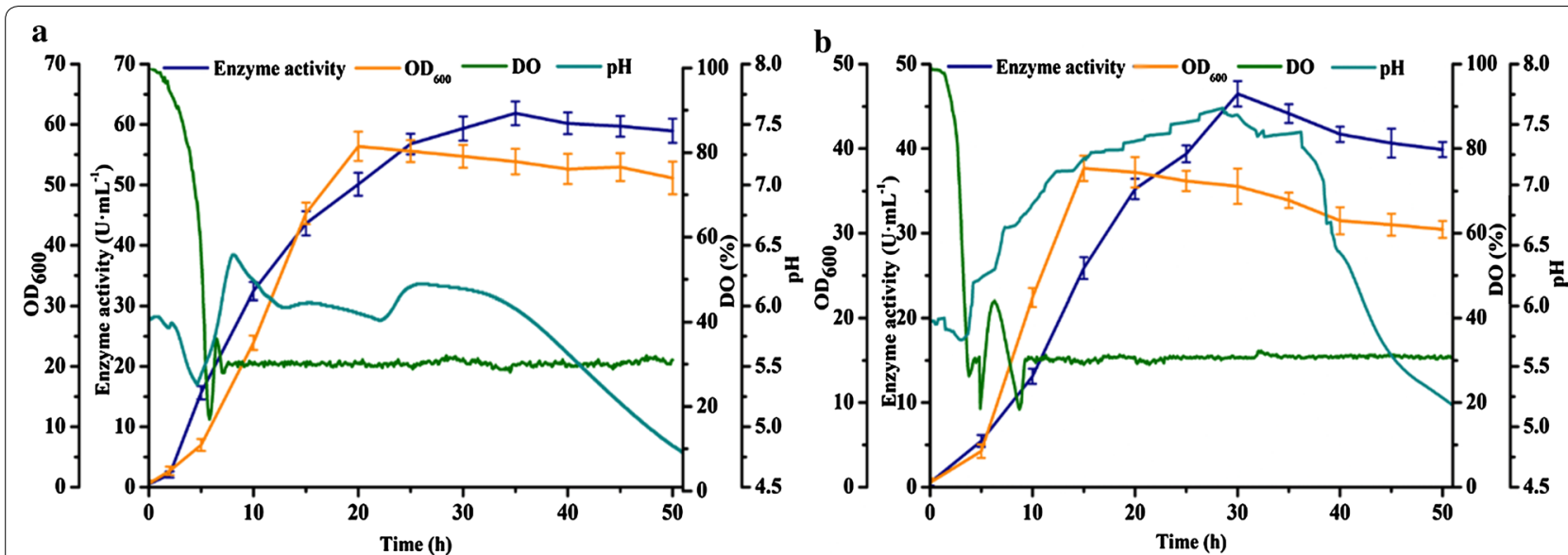

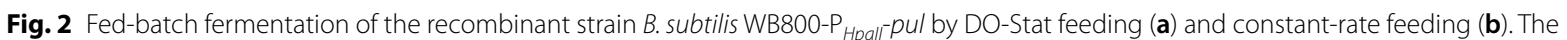
values of $\mathrm{OD}_{600}$ (orange curve), enzyme activity (blue curve), dissolved oxygen (green curve), and pH (light blue curve) were measured during the fermentation process. The averages of three independent experiments together with the corresponding standard deviations are shown for all values of $\mathrm{OD}_{600}$ and enzyme activity 
transferred to the fermenter needed to be adapted for a period. The cell concentration of the recombinant strain increased dramatically, the maximum value of $\mathrm{OD}_{600}$ was 56.4 when fermenting for $20 \mathrm{~h}$ and the enzyme activity reached the maximum value of $61.86 \mathrm{U} \mathrm{mL}^{-1}$ when fermenting for $35 \mathrm{~h}$. Compared with batch fermentation, the concentration of the recombinant strain and enzyme activity of fed-batch fermentation both increased. In terms of enzyme activity, the two feeding fermentations were increased by $10.3 \%$ and $46.8 \%$, respectively. This result indicated that carbon source deficiency was a major factor limiting the fermentation process.

\section{Effect of feeding carbon source}

To explore the effect of the feeding ingredients on the fermentation, we chose sucrose (the initial carbon source used in fermentation medium) and glucose (the most commonly used carbon source) as the carbon sources for fed-batch fermentation of the recombinant strain $B$. subtilis WB800- $\mathrm{P}_{\text {HpaII }}$-pul. As shown in the Fig. 3a, the maximum values of $\mathrm{OD}_{600}$ were 60.4 and 56.4 when feeding glucose and sucrose, respectively; while in the Fig. 3b, the enzyme activities reached the maximum values of $86.65 \mathrm{U} \mathrm{mL}^{-1}$ and $61.86 \mathrm{U} \mathrm{mL}^{-1}$ when feeding glucose and sucrose, respectively. The addition of carbon source was conducive to the growth of $B$. subtilis, indicating that the initial carbon source in the medium may not be sufficient for the fermentation process. Obviously, glucose was significantly better than sucrose for cell growth and production of enzyme from recombinant strain. As known, glucose is more easily used than sucrose, and thus improved the fermentation significantly. When glucose was fed, the extracellular enzyme activity reached $86.65 \mathrm{U} \mathrm{mL}^{-1}$ during the fermentation for $30 \mathrm{~h}$, which was $105.6 \%$ higher than the batch fermentation. Therefore, glucose was added to achieve the purpose of timely supplementing carbon source.

\section{Effect of feeding concentration}

Feeding concentration was one of the key parameters in the fermentation of pullulanase, which influenced the cell growth and distribution of metabolites (Xiao et al. 2017). We optimized the feeding concentration based on the determination of the optimum feeding rate, selecting different gradients of $300 \mathrm{~g} \mathrm{~L}^{-1}, 400 \mathrm{~g} \mathrm{~L}^{-1}$, and $500 \mathrm{~g} \mathrm{~L}^{-1}$, respectively.

As shown in the Fig. 4a, the maximum values of $\mathrm{OD}_{600}$ were $49.48,60.4$, and 37.85 when feeding glucose at $300 \mathrm{~g} \mathrm{~L}^{-1}, 400 \mathrm{~g} \mathrm{~L}^{-1}$, and $500 \mathrm{~g} \mathrm{~L}^{-1}$, respectively; while in the Fig. $4 \mathrm{~b}$, the corresponding enzyme activities reached the maximum values of $57.2 \mathrm{U} \mathrm{mL}^{-1}, 86.65 \mathrm{U} \mathrm{mL}^{-1}$, and $45.42 \mathrm{U} \mathrm{mL}^{-1}$ when fermenting for $30 \mathrm{~h}$, respectively. The profiles of cell growth and enzyme production exhibited similar trends. When the feeding concentration was $400 \mathrm{~g} \mathrm{~L}^{-1}$, the biomass and the enzyme activity both reached the highest values. When the feeding concentration was lower, it was not favorable for cell growth and enzyme production. However, when glucose solution $\left(500 \mathrm{~g} \mathrm{~L}^{-1}\right)$ was added at $0.1 \mathrm{~mL} \mathrm{~min}^{-1}$ at logarithmic growth phase $(8 \mathrm{~h})$, combining with the glucose generated from sucrose hydrolysis at the beginning stage of fermentation, glucose was further accumulated to the maximum concentration of $42 \mathrm{~g} \mathrm{~L}^{-1}$ during fermentation from 8 to $25 \mathrm{~h}$, then was gradually consumed during the
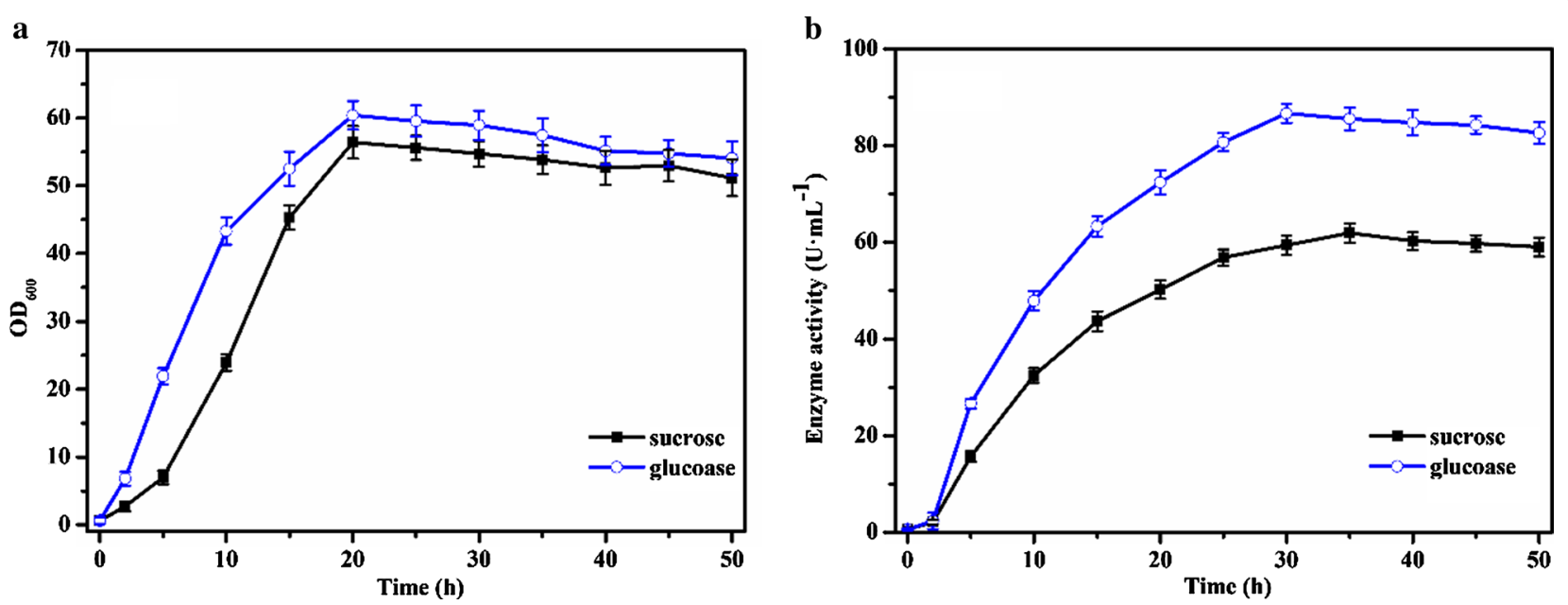

Fig. 3 Effect of feeding carbon source on $\mathrm{OD}_{600}$ (a) and enzyme activity (b). Glucose solution $\left(400 \mathrm{~g} \mathrm{~L}^{-1}\right)$ (blue curve) and sucrose solution $\left(400 \mathrm{~g} \mathrm{~L}^{-1}\right)$ (black curve) were used as the feeding carbon sources. The averages of three independent experiments together with the corresponding standard deviations are shown for all values of $\mathrm{OD}_{600}$ and enzyme activity 

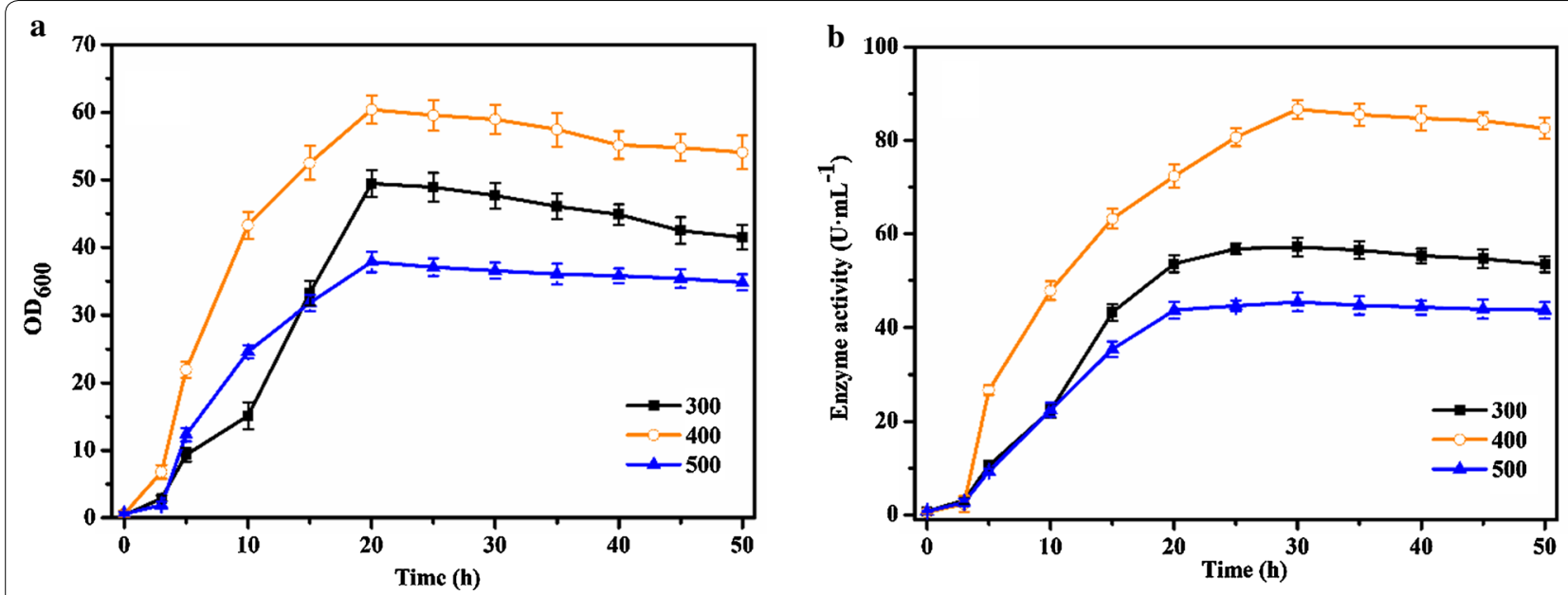

Fig. 4 Effect of feeding concentration on $\mathrm{OD}_{600}$ (a) and enzyme activity (b). Glucose was fed at $300 \mathrm{~g} \mathrm{~L}^{-1}$ (black curve), $400 \mathrm{~g} \mathrm{~L}^{-1}$ (orange curve), and $500 \mathrm{~g} \mathrm{~L}^{-1}$ (blue curve), respectively. The averages of three independent experiments together with the corresponding standard deviations are shown for all values of $\mathrm{OD}_{600}$ and enzyme activity

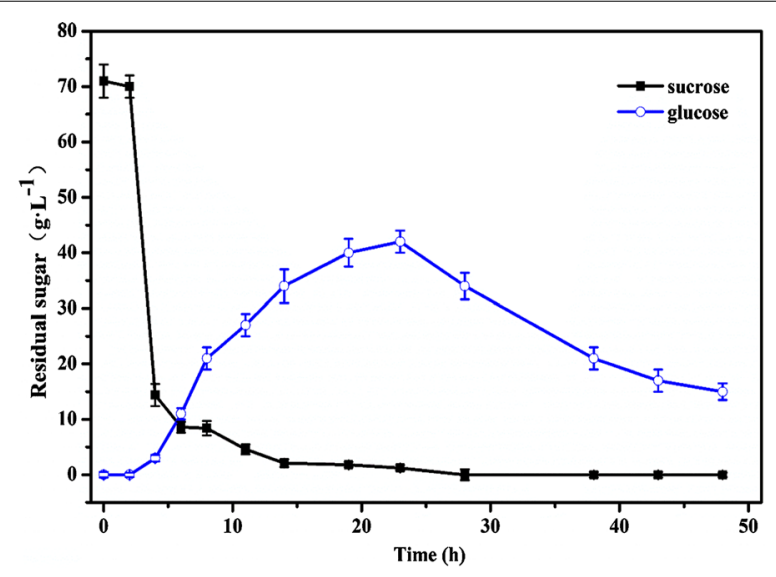

Fig. 5 Residual sugar including glucose (blue curve) and sucrose (black curve) during fed-batch fermentation by feeding $500 \mathrm{~g} \mathrm{~L}^{-1}$ glucose solution. The averages of three independent experiments together with the corresponding standard deviations are shown for all values of $\mathrm{OD}_{600}$ and enzyme

late logarithmic growth phase, resulting in decrease of glucose concentration to a detectable level about $20 \mathrm{~g} \mathrm{~L}^{-1}$ even in the stationary phase. During the fed-batch fermentation process, therefore, the glucose concentration increased at first and then decreased after fermentation for $25 \mathrm{~h}$ (Fig. 5). Because the residual sugar was continuously maintained at a detectable level even higher than $20 \mathrm{~g} \mathrm{~L}^{-1}$ in the stationary phase, which might have an inhibitory effect on cell growth and production of target enzyme, feeding glucose at $500 \mathrm{~g} \mathrm{~L}^{-1}$ was not favorable for the improvement of both biomass and enzyme activity. Based on the results of feeding concentration optimization, feeding glucose at $400 \mathrm{~g} \mathrm{~L}^{-1}$ was adopted for fed-batch fermentation of the recombinant strain $B$. subtilis WB800- $\mathrm{P}_{\text {HpaII }}$ - pul.

\section{Effect of $\mathrm{pH}$ on fermentation}

In batch culture, the pullulanase activity was $42.15 \mathrm{U} \mathrm{mL}^{-1}$ with the $\mathrm{OD}_{600}$ value of about 35 , where the $\mathrm{pH}$ at the end of fermentation was about 7.5 (Fig. 1); When feeding with sucrose and glucose, the $\mathrm{OD}_{600}$ value was increased to about 60 , while the $\mathrm{pH}$ at the end of the fermentation was 5 or less (Fig. 2). Because the $\mathrm{pH}$ value changed obviously during the fermentation process for both batch fermentation and fed-batch fermentation, it would be necessary to investigate the effect of constant $\mathrm{pH}$ on cell growth and enzyme production by controlling the $\mathrm{pH}$ of the fermentation broth.

As shown in Fig. 6, the overall trend of cell growth and enzyme production was consistent. The cell density reached a maximum at about $15-20 \mathrm{~h}$ of fermentation, and the enzyme activity reached a maximum at about $30 \mathrm{~h}$ of fermentation. However, the growth rate of the cells and the rate of the pullulanase synthesis were different, which might be related to $\mathrm{pH}$ values. When the $\mathrm{pH}$ value was 5.5 , the cells grew by a sharp speed within 3-15 h to reach a stable phase. At $20 \mathrm{~h}$, the maximum $\mathrm{OD}_{600}$ was 39.76 and the concentration of the cells remained unchanged. The enzyme activity reached a maximum of $46.5 \mathrm{U} \mathrm{mL}^{-1}$ during $30 \mathrm{~h}$ of fermentation. When the $\mathrm{pH}$ value was 6.5 , the recombinant strain continued to grew at a faster speed. The $\mathrm{OD}_{600}$ reached a maximum of 84.54 at $20 \mathrm{~h}$ of fermentation, and the maximum enzyme activity reached $102.75 \mathrm{U} \mathrm{mL}^{-1}$ after $35 \mathrm{~h}$ of fermentation. When the $\mathrm{pH}$ value was 7.5 , the $\mathrm{OD}_{600}$ 

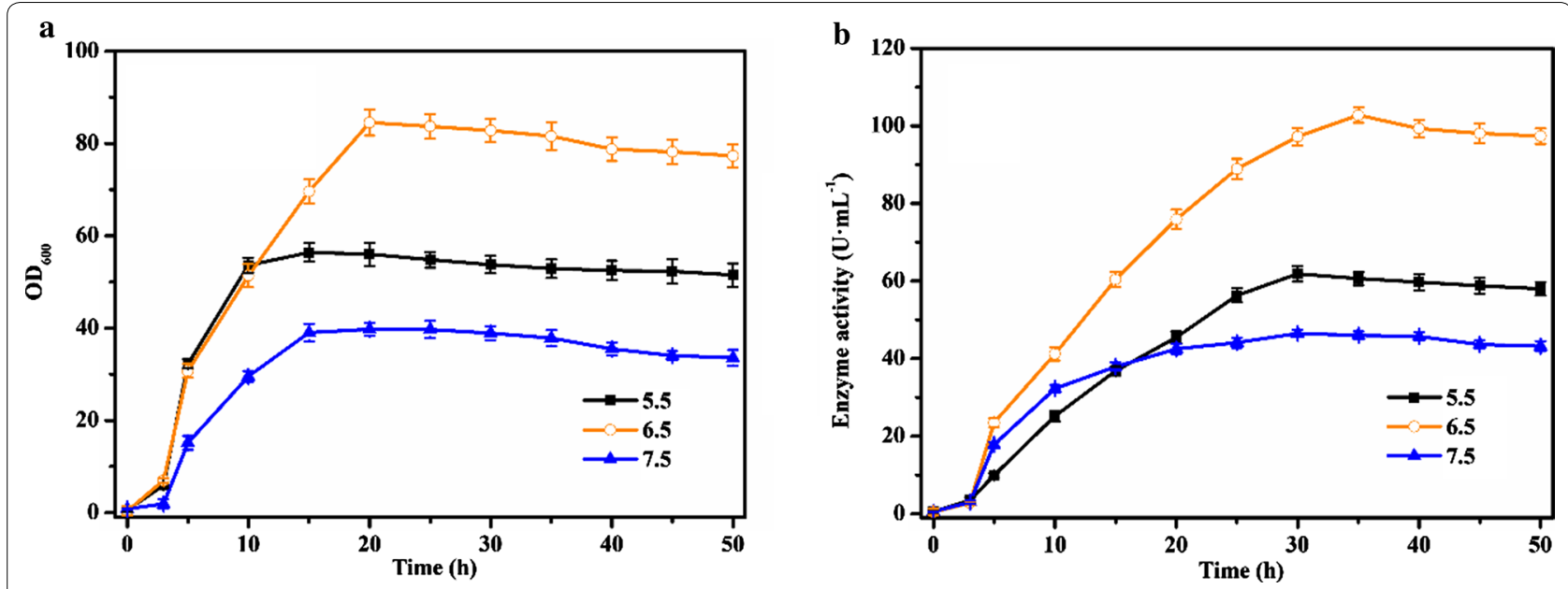

Fig. 6 Effect of controlled pH on $\mathrm{OD}_{600}(\mathbf{a})$ and enzyme activity (b). The pH value of fermentation broth of B. subtilis WB800-P $\mathrm{P}_{\text {Hpall }}$-pul was adjusted constantly at pH 5.5 (black curve), pH 6.5 (orange curve), and pH 7.5 (blue curve), respectively. The averages of three independent experiments together with the corresponding standard deviations are shown for all values of $\mathrm{OD}_{600}$ and enzyme activity

reached a maximum of 39.76 after $20 \mathrm{~h}$ of fermentation, and the maximum enzyme activity reached $46.5 \mathrm{U} \mathrm{mL}^{-1}$ after $30 \mathrm{~h}$ of fermentation. The $\mathrm{pH}$ value was an important parameter to ensure the normal reproduction and metabolism of microorganisms, affecting the fermentation significantly.

\section{Discussion}

In this study, batch fermentation and feeding fermentation were firstly compared. The recombinant strain concentration and enzyme activity of the feeding fermentations were better than the batch fermentation. The enzyme activity of DO-stat feeding strategy increased by $10.3 \%$ and the enzyme activity of constant-rate feeding strategy increased by $46.8 \%$, compared with batch fermentation.

Concerning the feeding mode, we used two methods for comparison, DO-Stat feeding and constant-rate feeding (Ding et al. 2014). Both feeding strategies were conducive to the accumulation of fermentation products. After comparison, it was found that constant-rate feeding in the logarithmic growth was better for growth. When the carbon in the medium was exhausted, the rate of aerobic metabolism of the recombinant strain was slowed down, resulting in a rapid increase in dissolved oxygen in the medium, and the dissolved oxygen rapidly decreased after the addition of carbon. Due to this observation, the agitation rate was controlled by dissolved oxygen feedback to maintain the proper level of nutrients in the medium. However, because this method had certain retardation and could not contemporary respond to the state in the fermenter, the feeding was slightly later than the ideal feeding time. In contrast, constant-rate feeding began to feed in late logarithmic growth, making up for the shortcomings of the former method and more suitable for the fermentation process.

Based on the optimization of feeding mode, it was necessary to explore the feeding ingredients and feeding concentrations for the further improvement of biomass and enzyme activity. By optimizing the feeding components, glucose was better than sucrose for accumulation of biomass and enzyme activity from the recombinant strain, with the increased $\mathrm{OD}_{600}$ of 60.4 and the enzyme activity of $86.65 \mathrm{U} \mathrm{mL}^{-1}$. Therefore, glucose can be added to achieve the purpose of timely supplementing carbon source. In addition, the phenomenon that microbes adopt different nutrient intake methods can be explained by the rational application of metabolic network topology and protein resources (Wang et al. 2019a, b). By investigating the effect of feeding concentration of glucose, when the glucose solution was $400 \mathrm{~g} \mathrm{~L}^{-1}$, it was beneficial to biomass and enzyme activity of the recombinant strain.

The addition of glucose solution had a great influence on the $\mathrm{pH}$ value in the fermentation process, making the recombinant strain more susceptible to acidic substances. The $\mathrm{pH}$ value affected the enzyme activity in the microbial cells and the charge of the microbial cell plasma membrane, as well as the dissociation of certain important nutrients and intermediate metabolites in the medium (Duan et al. 2006). When the $\mathrm{pH}$ was 6.5 , the $\mathrm{OD}_{600}$ reached a maximum of 84.54 at $20 \mathrm{~h}$ of fermentation, and the maximum enzyme activity reached 102.75 $\mathrm{U} \mathrm{mL} \mathrm{L}^{-1}$ after $35 \mathrm{~h}$ of fermentation, giving the $\mathrm{OD}_{600}$ and the enzyme activity of $39.9 \%$ and $18.6 \%$ increases compared to the fermentation under uncontrolled $\mathrm{pH}$, respectively. 
Consequently, by optimizing fermentation conditions including feeding mode, feeding amount, feeding composition, and $\mathrm{pH}$ value, the optimal conditions for pullulanase production from recombinant $B$. subtilis were obtained: inoculum volume $7 \%, \mathrm{pH}$ value 6.5 , dissolved oxygen level $30 \%$, constant-rate feeding of $400 \mathrm{~mL}$ glucose solution $\left(400 \mathrm{~g} \mathrm{~L}^{-1}\right)$ in late logarithmic growth. Finally, the production of the pullulanase was efficiently enhanced and the enzyme activity of $102.75 \mathrm{U} \mathrm{mL}^{-1}$ was obtained with $\mathrm{OD}_{600}$ of 84.54. Therefore, the enzyme activity was greatly improved by optimizing the feeding strategy and the corresponding fermentation conditions (Deng et al. 2018, Liu et al. 2012a, b), which provides a prerequisite for further amplification of the fermentation system to obtain higher enzyme activity.

\section{Abbreviations}

GRAS: Generally Recognized as Safe; DO: dissolved oxygen; $\mathrm{OD}_{600}$ : optical density at $600 \mathrm{~nm}$; LB: Luria-Bertani broth or agar plates; DNS: 3, 5-dinitrosalicylic acid.

\section{Acknowledgements}

We would like to thank Editage (http://www.editage.cn) for English language editing.

\section{Authors' contributions}

$Y N$ and $Y X$ conceived and designed the experiments. $Y Z, X Z$, and JB performed the experiments. $Y N$ and $Y Z$ analyzed the data and wrote the main manuscript. All authors contributed in writing and editing the manuscript. All authors read and approved the final manuscript.

\section{Funding}

Financial supports from the National Key R\&D Program of China

[2018YFC1604100], the National Natural Science Foundation of China (NSFC) [21676120, 31872891], the 111 Project [111-2-06], the High-end Foreign Experts Recruitment Program [G20190010083], the Program for Advanced Talents within Six Industries of Jiangsu Province [2015-NY-007], the National Program for Support of Top-notch Young Professionals, the Fundamental Research Funds for the Central Universities [JUSRP51504], the Project Funded by the Priority Academic Program Development of Jiangsu Higher Education Institutions, Top-notch Academic Programs Project of Jiangsu Higher Education Institutions, the Jiangsu Province "Collaborative Innovation Center for Advanced Industrial Fermentation"Industry Development Program, and the National First-Class Discipline Program of Light Industry Technology and Engineering [LITE2018-09] are greatly appreciated.

\section{Availability of data and materials}

The data supporting the conclusions of this article are included within the article. Data and materials can also be requested from the corresponding author.

\section{Ethics approval and consent to participate}

Not applicable.

\section{Consent for publication}

Not applicable.

\section{Competing interests}

The authors declare that they have no competing interests.

\section{Author details}

${ }^{1}$ School of Biotechnology and Key Laboratory of Industrial Biotechnology of Ministry of Education, Jiangnan University, 1800 Lihu Road, Wuxi 214122,
China. ${ }^{2}$ State Key Laboratory of Food Science and Technology, Jiangnan University, 1800 Lihu Road, Wuxi 214122, China.

Received: 28 November 2019 Accepted: 6 January 2020

Published online: 18 January 2020

\section{References}

Beaulieu L, Groleau D, Miguez CB, Jette JF, Aomari H, Subirade M (2005) Production of pediocin PA-1 in the methylotrophic yeast Pichia pastoris reveals unexpected inhibition of its biological activity due to the presence of collagen-like material. Protein Expr Purif 43:111-125

Chen WB, Nie Y, Xu Y (2012) Signal peptide-independent secretory expression and characterization of pullulanase from a newly isolated Klebsiella variicola SHN-1 in Escherichia coli. Appl Biochem Biotechnol 169:41-54

Deng Y, Nie Y, Zhang Y, Wang Y, Xu Y (2018) Improved inducible expression of Bacillus naganoensis pullulanase from recombinant Bacillus subtilis by enhancer regulation. Protein Expr Purif 148:9-15

Ding J, Gao MJ, Hou GL, Liang KX, Yu RS, Li Z, Shi ZP (2014) Stabilizing porcine interferon-alpha production by Pichia pastoris with an ethanol on-line measurement based DO-Stat glycerol feeding strategy. J Chem Technol Biotechnol 89:1948-1953

Duan S, Shi Z, Feng H, Duan Z, Mao Z (2006) An on-line adaptive control based on $\mathrm{DO} / \mathrm{pH}$ measurements and ANN pattern recognition model for fedbatch cultivation. Biochem Eng J 30:88-96

Gao M, Shi Z (2013) Process control and optimization for heterologous protein production by Methylotrophic Pichia pastoris. Chin J Chem Eng 21:216-226

Huang H, Ridgway D, Gu T, Moo-Young M (2004) Enhanced amylase production by Bacillus subtilis using a dual exponential feeding strategy. Bioprocess Biosyst Eng 27:63-69

Kang J, Park KM, Choi KH, Park CS, Kim GE, Kim D, Cha J (2011) Molecular cloning and biochemical characterization of a heat-stable type I pullulanase from Thermotoga neapolitana. Enzyme Microb Technol 48:260-266

Kubiak M, Borkowska M, Bialas W, Korpys P, Celinska E (2019) Feeding strategy impacts heterologous protein production in Yarrowia lipolytica fed-batch cultures-insight into the role of osmolarity. Yeast 36:305-318

Labbeiki G, Attar H, Heydarinasab A, Sorkhabadi S, Rashidi A (2014) Enhanced oxygen transfer rate and bioprocess yield by using magnetite nanoparticles in fermentation media of erythromycin. DARU J Pharm Sci 22:66

Leathers TD (2003) Biotechnological production and applications of pullulan. Appl Microbiol Biotechnol 62:468-473

Liu L, Du G, Chen J, Wang M, Sun J (2008) Influence of culture modes on the microbial production of hyaluronic acid by Streptococcus zooepidemicus. Biotechnol Bioproc E 13:269-273

Liu Y, Bo J, Wang Y, Zhang Z, Wang L, Lu F (2012a) Optimization of fermentation conditions for the pullulanase production by engineered Bacillus subtilis. Food Res Dev 33:136-140

Liu Y, Liu L, Chen J, Li J, Du G, Chen J (2012b) Effects of carbon sources and feeding strategies on heparosan production by Escherichia coli K5. Bioproc Biosyst Eng 35:1209-1218

Nakamura Y (1996) Some properties of starch debranching enzymes and their possible role in amylopectin biosynthesis. Plant Sci 121:1-18

Park YS, Kai K, lijima SJ, Kobayashi T (1992) Enhancede $\beta$-galactosidase production by high cell-density culture of recombinant Bacillus subtilis with glucose concentration control. Biotechnol Bioeng 40:686-696

Prentice LH, Ehrenfels NB, Sisk WP (2007) Improving performance of mammalian cells in fed-batch processes through bioreactor evolution. Biotechnol Prog 23:458-464

Shiraishi F, Kawakami K, Kusunoki K (1985) Kinetics of condensation of glucose into maltose and isomaltose in hydrolysis of starch by glucoamylase. Biotechnol Bioeng 27:498-502

Singh RS, Saini GK, Kennedy JF (2010) Covalent immobilization and thermodynamic characterization of pullulanase for the hydrolysis of pullulan in batch system. Carbohyd Polym 81:252-259

Son YJ, Park KH, Lee SY, Oh SJ, Kim CK, Choi BT, Park YC, Seo JH (2007) Effects of temperature shift strategies on human preproinsulin production in the fed-batch fermentation of recombinant Escherichia coli. Biotechnol Bioprocess Eng 12:556-561 
van der Maarel MJEC, van der Veen B, Uitdehaag JCM, Leemhuis H, Dijkhuizen $L$ (2002) Properties and applications of starch-converting enzymes of the alpha-amylase family. J Biotechnol 94:137-155

Wang J, Liu S, Du G, Chen J (2014) Construction and fermentation optimization of a recombinant Bacillus subtilis producing alkaline amylase. J Food Sci Biotechnol 35:296-302

Wang K, Tian Y, Zhou N, Liu D, Zhang D (2018) Studies on fermentation optimization, stability and application of prolyl aminopeptidase from Bacillus subtilis. Process Biochem 74:10-20

Wang X, Xia K, Yang X, Tang C (2019a) Growth strategy of microbes on mixed carbon sources. Nat Commun 10:1-7

Wang Y, Chen S, Zhang Z, Zhang Y, Wang X, Nie Y, Xu Y (2019b) Enhancement of the production of Bacillus naganoensis pullulanase in recombinant Bacillus subtilis by integrative expression. Protein Expr Purif 159:42-48

Xiao Z, Gu R, Hou X, Zhao J, Zhu H, Lu J (2017) Non-sterilized fermentative production of acetoin with 2,3-butanediol as a main byproduct from maize hydrolysate by a newly isolated thermophilic Bacillus strain. J Chem Technol Biotechnol 92:2845-2852

Yadav J, Balabantaray S, Patra N (2017) Statistical optimization of fermentation conditions for the improved production of poly-hydroxybutyrate from Bacillus subtilis. Chem Eng Commun 204:1122-1128

Zhu Y, Liu Y, Li J, Shin HD, Du G, Liu L, Chen J (2015) An optimal glucose feeding strategy integrated with step-wise regulation of the dissolved oxygen level improves $\mathrm{N}$-acetylglucosamine production in recombinant Bacillus subtilis. Bioresour Technol 177:387-392

\section{Publisher's Note}

Springer Nature remains neutral with regard to jurisdictional claims in published maps and institutional affiliations.

\section{Submit your manuscript to a SpringerOpen ${ }^{\odot}$ journal and benefit from:}

- Convenient online submission

- Rigorous peer review

- Open access: articles freely available online

- High visibility within the field

- Retaining the copyright to your article

Submit your next manuscript at springeropen.com 